\title{
Miejscowości uzdrowiskowe w Austrii, Czechach, Niemczech i na Słowacji: status prawny i regulacyjne determinanty funkcjonowania
}

\begin{abstract}
Streszczenie
W Austrii, Czechach, RFN i na Słowacji istnieje całkiem znacząca regulacja szczególna dotycząca funkcjonowania miejscowości uzdrowiskowych i uzdrowisk. W państwach federalnych (w Austrii i RFN) jest ona tworzona zarówno na poziomie federalnym, jak i landowym, jednak z większą intensywnością na tym drugim poziomie. Regulacja każdego $\mathrm{z}$ analizowanych państw ma służyć zapewnieniu publicznej gwarancji jakości właściwości naturalnych miejscowości uzdrowiskowych i uzdrowisk. Jednocześnie owa regulacja ogranicza wybór wariantów rozwojowych takich miejscowości i miejsc. Koszt alternatywny jest w tym wypadku pokrywany przez premie cenowe za usługi w nich świadczone, jak również w postaci specjalnych podatków. Dochody z nich są jednak znaczone w tym sensie, że muszą być przeznaczane na rozwój cech i funkcji uzdrowiskowych danej miejscowości. Warto podkreślić, że w badanych systemach prawnych nie stwierdzono szczególnego, dostępnego jedynie dla miejscowości uzdrowiskowych i dla nich zaprojektowanego, systemu subwencjonowania $\mathrm{z}$ budżetów regionalnych czy centralnych.
\end{abstract}

Słowa kluczowe: miejscowości uzdrowiskowe, uzdrowiska, sanatorium, planowanie przestrzenne, ochrona środowiska, opodatkowanie środowiskowe

Spa-Towns and Health Resorts in Austria, the Czech Republic, Germany and Slovakia: Their Status and the Determinants of Their Functioning

\begin{abstract}
There is a significant regulation concerning spa-towns and/or health resorts in Austria, the Czech Republic, Germany and Slovakia. In federal states (i.e. in Austria and Germany),
\end{abstract}


this regulation is adopted at the federal and länder (i.e. regional) level, yet the latter one is definitely more intensive. The spa-related regulation in each state considered is meant to provide public warranty as to the quality of natural features of spa-towns or health resorts. In the same time, this regulation sets significant constraints with regard to the choice of development patterns available to spas. The resulting opportunity cost can, however, be covered by price premia chargeable in spas and by special taxes levied only in spas. The tax income arising from them, however, is earmarked as it can be designated for improvements of spa-related features and functions of a given town or site. In the countries considered, there is no specifically designed subvention scheme which could be used only by spa-towns or health resorts.

Keywords: spas, spa-towns, sanatorium, spatial planning, environmental protection, environmental taxation

W systemach prawnych, które uznają szczególne znaczenie uzdrowiskowych miejscowych właściwości klimatu oraz innych czynników o charakterze lokalnym, funkcjonuje kategoria miejscowości uzdrowiskowych lub uzdrowisk ( „miejsc uzdrowiskowych”). Te korzystają ze szczególnej, gwarantowanej prawnie, publicznej rękojmi jakości ich walorów uzdrowiskowych; jednocześnie dotyczy ich szczególny reżim ochrony tych walorów, ograniczający możliwość wyboru kierunków ich rozwoju jedynie do tych, które pozwalają zachować szczególny status uzdrowiskowy. Z tego powodu uzdrowiska te muszą uzyskiwać premie cenowe za świadczone w nich usługi - realizowane przede wszystkim w formule właściwej dla świadczenia sektora prywatnego, co nie wyklucza możliwości zakupu tych usług z funduszy publicznych. Ponieważ jednak w takich miejscowościach wytwarzane jest szczególne, zlokalizowane dobro publiczne w postaci utrzymywania czynników uzdrowiskowych, uzasadnione jest także pozyskiwanie szczególnych dochodów przeznaczonych na to właśnie dobro przez sektor publiczny.

W artykule przedstawiono analizę zasad ustalania statusu miejscowości uzdrowiskowych oraz zasadnicze reguły ich funkcjonowania w wybranych państwach Unii Europejskiej: w Austrii, Czechach, RFN i na Słowacji. Wybór w analizie reżimów prawnych tych państw wynika z najbardziej ugruntowanej właśnie w nich tradycji prawnej regulacji funkcjonowania miejscowości uzdrowiskowych, biorącej się z ruchu sanatoryjnego zainicjowanego w jego obecnej formie przez Hermanna Brehmera, który w 1854 r. założył w miejscowości Görbersdorf (czyli obecnym Sokołowsku) pierwsze sanatorium (przeciwgruźlicze) zorganizowane na zasadach, które można uznać za właściwe również z punktu widzenia dzisiejszej wiedzy naukowej (Dormandy, 1999: 150-151). Przyjęcie właśnie tej perspektywy jest przy tym logiczne również 
dlatego, że i polska regulacja funkcjonowania tego typu miejscowości mieści się $\mathrm{w}$ ramach tej tradycji.

W szczególności, w przedstawionej analizie odniesiono się do kwestii nadania statusu uzdrowiska oraz kryteriów branych pod uwagę $\mathrm{w}$ takim przypadku. Tak więc analiza dotyczy tego:

a) w jakiej, rozumianej systemowo, prawnej postaci realizowana jest polityka państwa dotycząca uzdrowisk?

b) jakim podmiotom (obszarom czy może obiektom wraz z określoną, wymaganą przez prawo, infrastrukturą) nadawany jest status uzdrowiskowy?

c) jakie są zasadnicze warunki uzyskania statusu uzdrowiskowego i jego utrzymania?

d) jakie są podstawowe regulacje dotyczące szczególnych form finansowania miejscowości uzdrowiskowych? - tu jednak przy pozostawieniu analizy na pewnym poziomie ogólności z uwagi na to, że dokładniejszą prezentację tego zagadnienia zaproponowałem w jeszcze aktualnym piśmiennictwie naukowym (Nowak-Far, 2017: 13-22).

W artykule przyjęto zaznaczone w zleceniu rozdzielenie pojęć „uzdrowiska” i „gminy uzdrowiskowej” (określanej tu - za źródłowymi tekstami prawnymi - jako „miejscowość uzdrowiskowa”), które w poszczególnych reżimach prawnych jest również uwzględnianie. Przyjęto w nim także konwencje prawne analizowanych systemów prawnych dotyczące używania określeń takich jak „uzdrowisko”, „złoże” czy „miejscowość uzdrowiskowa”. W artykule uznano przybliżoną równoważność znaczenia wspomnianych określeń prawa austriackiego i niemieckiego, czeskiego oraz słowackiego. Przyjęty klucz równoważności znaczeń przedstawia się następująco:

Tabela 1. Przyjęta w opracowaniu ekwiwalencja znaczeń zasadniczych pojęć prawa austriackiego, czeskiego, niemieckiego i słowackiego

\begin{tabular}{|l|l|l|l|}
\hline \multicolumn{1}{|c|}{ Określenie polskie } & \multicolumn{1}{|c|}{$\begin{array}{c}\text { Prawo austriackie } \\
\text { i niemieckie }\end{array}$} & \multicolumn{1}{|c|}{ Prawo czeskie } \\
\hline Złoże uzdrowiskowe & $\begin{array}{l}\text { Heilvorkomme Heilquelle, } \\
\text { Heilbrunn }\end{array}$ & Léčivý zdroj & Liečivý zdroj \\
\hline Uzdrowisko & Heilbad* & Léčebne lazne & Liečebne kúpelý \\
\hline Miejscowość uzdrowiskowa & Kurort* $^{\star}$ & Lázenske místo & Kúpel'ne miesto \\
\hline
\end{tabular}

*W prawie austriackim i niemieckim stosuje się także odpowiedniki tych ogólnych określeń, przymiotnikowo dookreślające źródło właściwości leczniczych, które są podstawą uznania uzdrowiska lub miejscowości uzdrowiskowej (np. Luftkurort, Seeheilbad) albo stosowanej metody leczniczej (np. Kneippheilbad)

Źródło: opracowanie własne.

Artykuł pomija zagadnienie (skądinąd istotnych) funkcji miejscowości uzdrowiskowych w systemie ochrony zdrowia państw objętych przedstawioną w nim analizą. 
Skupia się przecież na uwidocznionych w regulacji lub determinowanych przez nią aspektach polityki publicznej, dotyczącej tych miejscowości jako takich, nie zaś ich roli wynikającej z prawnego zaklasyfikowania ich jako uzdrowiskowych.

\section{Prawo Unii Europejskiej a status miejscowości uzdrowiskowych}

Prawo Unii Europejskiej nie reguluje działalności uzdrowisk. Reguluje ono jednak niektóre aspekty ich działalności. W szczególności zakresem regulacji prawa UE objęte jest zagadnienie ponadgranicznego oferowania usług uzdrowiskowych, a także korzystania z nich (również w kontekście finansowanych ze środków publicznych usług o charakterze leczniczym/medycznym). Istotna regulacja unijna działania uzdrowisk dotyczy jakości i zakresu informacji konsumenckiej odnoszącej się do usług oferowanych w związku z posiadanymi przez dane uzdrowisko zasobami/ walorami. Istotną regulacją prawa unijnego dotyczącą funkcjonowania uzdrowisk i miejscowości uzdrowiskowych jest ta związana $\mathrm{z}$ ich finansowaniem - w tym w szczególności regulacja pomocy publicznej.

W odniesieniu do standardu informacji konsumenckiej odnoszącej się do jakości i zakresu usług oferowanych w związku z posiadanymi przez dane uzdrowisko zasobami, jak również jakością produktów pozyskiwanych ze źródeł uzdrowiskowych, zastosowanie mają regulacje ogólne wymagające rzetelności i sprawdzalności owych informacji (Dyrektywa Rady, 1980: 1; Dyrektywa Komisji, 2003: 34).

$\mathrm{W}$ odniesieniu do pomocy publicznej istotnym postanowieniem prawa UE jest art. 107 ust. 1 Traktatu o funkcjonowaniu Unii Europejskiej (TFUE), zakazujący przyznawania przez państwa członkowskie lub przy użyciu zasobów państwowych, w jakiejkolwiek formie, takiej pomocy, która „zakłóca lub grozi zakłóceniem konkurencji poprzez sprzyjanie niektórym przedsiębiorstwom lub produkcji niektórych towarów" w zakresie, w jakim wpływa to na wewnątrzunijną wymianę handlową. Finansowe, oparte na zasadzie selektywności, wspieranie świadczenia usług uzdrowiskowych jako takie objęte jest zakresem stosowania art. 107 TFUE, a więc i zakazem w nim sformułowanym. Jednocześnie, w zakresie, w jakim uzdrowiska (rozumiane jako przedsiębiorstwa albo grupy przedsiębiorstw) funkcjonują w krajowym systemie świadczeń zdrowotnych, ich finansowanie nie jest objęte reżimem art. 107 TFUE - przede wszystkim dlatego, że działa tu wyjątek art. 106 ust. 2 tego traktatu, zgodnie z którym takie świadczenia mogą być uznane za tzw. „świadczenia usług w ogólnym interesie gospodarczym”. W odniesieniu do nich wspomniany zakaz udzielania pomocy publicznej stosuje się jedynie w zakresie, w jakim nie może 
stanowić on „prawnej lub faktycznej przeszkody” w wykonywaniu powierzonych tym podmiotom zadań. W zakresie, $\mathrm{w}$ jakim funkcjonowanie uzdrowisk mieści się w krajowym systemie świadczenia opieki zdrowotnej, ich finansowanie nie jest objęte niedozwoloną pomocą publiczną.

Jeszcze inaczej kwestia finansowania działalności przedstawia się w odniesieniu do miejscowości uzdrowiskowych - które przecież są gminami albo fragmentami terytoriów gmin (y), których szczególne walory uzdrowiskowe zostały urzędowo uznane. Te są bowiem elementem ogólnego, krajowego systemu finansowania gmin, opierającego się zazwyczaj na stanowieniu w prawie krajowym własnych fiskalnych źródeł ich działalności oraz określeniu systemu transferów pomiędzy nimi a wyższymi poziomami administracyjnego podziału terytorialnego państwa, w którym one funkcjonują. Zagadnienie wspomnianych transferów (zwykle mających postać subwencji lub dotacji płynących z budżetu, którego dysponentem jest organ wyższego szczebla podziału terytorialnego państwa do budżetów gminnych) należy do zakresu wyłącznych kompetencji państw członkowskich UE - jako zagadnienie natury fiskalnej nie jest objęte nawet środkami harmonizacji prawa krajowego na poziomie unijnym. W tym wypadku nie ma również problemu pomocy publicznej, bo wspomniane transfery są dokonywane w ramach finansowania zadań podmiotów administracji publicznej. Jedynie ewentualne wykorzystanie środków pochodzących z takich transferów na rzecz przedsiębiorstw może stanowić pomoc publiczną w zakresie, w jakim spełnione są wspomniane już kryteria art. 107 TFUE.

\section{Postacie krajowych regulacji dotyczących funkcjonowania miejscowości uzdrowiskowych i uzdrowisk}

W Austrii regulacja prawna dotycząca uzdrowisk jest rozproszona na poziomie federalnym i systemów prawnych poszczególnych landów (krajów). Na poziomie federalnym obowiązuje regulacja natury ramowej, ujmująca podstawowe w tym zakresie zagadnienia: Ustawa federalna z 2 grudnia 1958 r. o naturalnych złożach leczniczych i uzdrowiskach (dalej BHK) (Bundesgesetz..., 1958: 243). W $\$ 1$ ust. 1 (w związku z ust. 2 i ust. 6-7) akt ten wymaga, by na terenie uzdrowiska (niem. Kurort) znajdowały się źródła/złoża jakichś szczególnie wartościowych dla zdrowia czynników: źródła wód zdrowotnych (niem. Heilquellen), borowin (niem. Heilpeloide) albo innych czynników korzystnych dla zdrowia (określanych w BHK wspólnym mianem niem. Heilfaktoren). Czynniki klimatyczne i inne (w tym uwarunkowania dotyczące niskich poziomów hałasu) należą do tej ostatniej grupy ( $\$ 1$ ust. $5 \mathrm{BHK}$ ). W odniesieniu do uzdrowisk muszą owe czynniki wykazywać stałość i być naukowo 
udowodnione ( $\$ 2$ ust. 4 BHK). Dokładne wymagania w tym zakresie mają jednak określać regulacje landowe.

Podstawowym aktem prawnym regulującym kwestie funkcjonowania uzdrowisk jest w Republice Czeskiej Ustawa z 13 kwietnia 2001 r. o naturalnych źródłach leczniczych, źródłach naturalnych wód mineralnych, naturalnych uzdrowiskach leczniczych i miastach uzdrowiskowych oraz zmianie ustaw z tym związanych (tzw. ustawa uzdrowiskowa, czes. lázeňský zákon, dalej LZ) (Zákon..., 2001). Akt ten określa m.in. ogólne warunki identyfikacji, ochrony i korzystania ze złóż leczniczych oraz funkcjonowania uzdrowisk i miast uzdrowiskowych (czes. lázeňských míst). W myśl $\$ 2$ ust. 4 LZ (w związku z $\$ 28$ ust. 1 oraz $\$ 25$ ust. 1 LZ) miastem uzdrowiskowym jest uznany zgodnie z regulacją LZ obszar gmin (y) albo część obszaru gmin (y), na którym znajduje się uzdrowisko naturalne. Za takie akt ten uznaje także „zbiór zdrowotnych i innych powiązanych urządzeń służących do wykonywania rehabilitacji uzdrowiskowej" (\$2 ust. $3 \mathrm{LZ}$ ).

W Republice Federalnej Niemiec ogólna federalna regulacja dotycząca funkcjonowania uzdrowisk jest częścią piątej księgi Kodeksu Społecznego (niem. Sozial Gesetzubuch - Fünftes Buch (V) Gesetzliche Krankenversicherung, dalej SGB V) (Gesetz..., 1988). Ma ta regulacja charakter szczątkowy, gdyż zasadniczo dotyczy uprawnień osób uczestniczących w niemieckim systemie zabezpieczenia społecznego do leczenia uzdrowiskowego oraz finansowania świadczeń zdrowotnych oferowanych w uzdrowiskach. Kwestia samego nadania statusu uzdrowiska lub miejscowości uzdrowiskowej oraz bardziej szczegółowych zasad ich funkcjonowania jest materią zastrzeżoną w RFN do kompetencji landów. Ponadto, znaczącą rolę w funkcjonowaniu uzdrowisk i miejscowości uzdrowiskowych odgrywa samoregulacja, tj. standardy przyjęte wspólnie przez podmioty prowadzące działalność uzdrowiskową w ramach ich własnego stowarzyszenia o nazwie Deutscher Helbäderverband e. V. (dalej DHV).

Na Słowacji podstawowym aktem prawnym dotyczącym funkcjonowania uzdrowisk jest Ustawa z 27 października 2005 r. o naturalnych wodach leczniczych, naturalnych termach, uzdrowiskach i naturalnych wodach mineralnych, jak również o zmianie i uzupełnieniu niektórych ustaw (dalej jest ona określana jako „KZ”, słow. kupel’nýzakon, tj. „ustawa uzdrowiskowa”) (Zákon..., 2005). Akt ten dotyczy m.in. warunków prowadzenia działalności uzdrowiskowej, prawnego statusu miejscowości uzdrowiskowych (słow. kúpel’ne miesto), jak również ochrony środowiska uznanego za uzdrowiskowe (słow. kúpel'né prostredie). 


\section{Uznanie statusu uzdrowiska lub miejscowości uzdrowiskowej}

\section{Regulacja austriacka}

W Austrii uznanie jakichkolwiek źródeł/złóż za uzdrowiskowe oraz uznanie miejscowości za miejscowość uzdrowiskową jest aktem, do wydania którego - na mocy $\$ 2$ ust. $1 \mathrm{w}$ związku z $\$ 5$ ust. 1 BHK - kompetencje mają właściwe dla miejsca ich położenia rządy landowe ( $w$ odniesieniu do uzdrowisk decyzję podejmuje szef rządu landowego - Landeshauptmann - na podstawie operatu sanitarnego na wniosek właściciela, zaś co do uznania miejscowości za uzdrowiskową na wniosek gminy). Zasadniczymi wymaganiami miejscowości uzdrowiskowej jest spełnianie właściwych ogólnych warunków naturalnych oraz posiadanie co najmniej jednego ze źródeł szczególnie wartościowych dla zdrowia czynników, jak również urząazeń koniecznych do ich eksploatacji, a także spełnianie „ogólnych wymogów higienicznych” (niem. allgemeine hygienische Voraussezungen). W decyzjach dotyczących uznania uzdrowiska organy rządu landowego mogą określać wymagania dotyczące infrastruktury eksploatacyjnej ( $\$ 7$ ust. 1 BHK).

Określenie konkretnego stopnia spełniania wymogów uzdrowiskowych leży w kompetencji landów. One także mają kompetencje do klasyfikacji danego uzdrowiska jako uzdrowiska ogólnego (niem. Heilbad), uzdrowiska/miejscowości o zdrowym klimacie (niem. heilklimatischer Kurort), uzdrowiska/miejscowości mającej zdrowe (dobroczynne) powietrze (niem. Luftkurort) albo jako takiego, którego nazwa nawiązuje do wszelkich innych walorów zdrowotnych ( $\$ 6$ ust. 1 BHK).

Jak już wspomniano, uznanie miejscowości uzdrowiskowej następuje na wniosek gminy bądź gmin starających się o taki status ( $\$ 5$ ust. 1 BHK). Zgodnie z $\$ 2$ ust. 1 BHK, uznanie złoża uzdrowiskowego (niem. Heilvorkommen) może nastąpić jedynie na wniosek jego posiadacza (niem. Eigentümer) - przez co rozumie się osobę, która ma taki tytuł prawny do nieruchomości, który umożliwia czerpanie z niej pożytków. Także eksploatacja złoża wymaga uzyskania koncesji (niem. Bewilligung); tę wydaje rząd landowy na wniosek właściciela złoża albo podmiotu je eksploatującego (niem. Nutzungsberechtige des Vorkommens) - jeżeli nie jest nim właściciel złoża (zob. §3 ust. 1 BHK). Warunkiem uzyskania koncesji jest zapewnienie technicznych możliwości eksploatacji złoża, jak również spełnienie wymagań sanitarno-higienicznych (ust. 2 lit. b i c tego samego paragrafu BHK). Eksploatacja uznanego złoża bez uzyskania koncesji jest zakazana. 
Zgodnie z $\$ 20$ BHK każde z uznanych złóż uzdrowiskowych jest wpisywane do urzędowego spisu (katastru) naturalnych złóż uzdrowiskowych Austrii (niem. Kataster der natürlichen Heilvorkommen Österreichs) prowadzonego przez Federalny Zakład Badań Eksperymentalno-Farmakologicznych i Balneologicznych (niem. Bundesstaatlichen Anstalt für expremintell-pharmakologische und balneologische Untersuchungen) w Wiedniu. Wpis do rejestru ma charakter deklaratoryjny, zaś jego zasadniczą funkcją jest umożliwienie konsumentom weryfikacji informacji o danym złożu występujących w obrocie handlowym.

Zgodnie z $\$ 11$ ust. 1 uznanie miejscowości za uzdrowisko łączy się z wyznaczeniem przez władzę landową obszaru uzdrowiskowego (niem. Kurbezirk). Jego granice mogą, ale nie muszą pokrywać się z granicami gmin (y). W ramach takiego obszaru gmina może ustanawiać środki ochrony złóż uzdrowiskowych - także w odniesieniu do reżimu wykonywania praw własności gruntu. Zasada ta implikuje dokładną inwentaryzację obiektów i innych składników infrastruktury, która może się nad złożem uzdrowiskowym, jak również w obrębie obszaru uzdrowiskowego znajdować - jest tak tym bardziej, że $\$ 9$ ust. 5 BHK wymaga uzgodnienia z rządem landowym każdej zmiany zagospodarowania przestrzennego, w tym dotyczącej urządzeń uzdrowiskowych. Wspomniany reżim ochronny implikuje zaś możliwość wprowadzenia administracyjnych ograniczeń w planowanych zmianach tej infrastruktury.

Regulacja landowa $\mathrm{w}$ znacznym stopniu powiela rozwiązania prawne przyjęte na poziomie federalnym (w BHK). Na przykład tyrolska Ustawa z 4 lutego 2004 o naturalnych uzdrowiskach i miejscowościach uzdrowiskowych (dalej THK) (Gesetz..., 2004: 9) $)^{1}$ ustanawia takie same zasadnicze wymogi uzdrowisk i miejscowości uzdrowiskowych jako federalna BHK. Tak samo jak BHK, tyrolska THK $\mathrm{w} \$ 2$ wymaga uznania uzdrowisk w drodze wydania przez administrację landową (tj. w praktyce w akcie wydawanym przez Landeshauptmanna), na wniosek posiadacza (niem. Inhaber) złoża o właściwościach uzdrowiskowych ${ }^{2}$ stosownej decyzji, po przeprowadzeniu odpowiednich badań wstępnych, obejmujących pełną analizę (niem. Vollanalyse) złoża. Odrębnością regulacyjną w stosunku do BHK jest to, że w takiej decyzji dokładne wskaźniki i wymogi, które będą kontrolowane w przyszłości, ustala się w porozumieniu z administracją okręgową (niem. Bezirksverwaltung). Weryfikacja właściwości uzdrowiskowych staje się ostateczna (a zatem i decyzja w tej sprawie także się staje ostateczna) po 6 miesiącach od daty uznania wtedy, gdy

Regulacje innych landów Austrii są podobne.

2 Wymóg ten różni się od wymogu BHK: w BHK jest mowa o właścicielu, natomiast w THK o posiadaczu. 
właściwe organy administracji okręgowej nie stwierdzą takich zmian źródła, które powodowałyby, że wspomniane wskaźniki nie byłyby utrzymane ( $\$ 2$ ust. 8 THK).

Także więc w wypadku regulacji landowej implikacją przyjętych przepisów jest to, że uznanie złoża lub uzdrowiska jest oparte na dokumentacji uwzględniającej istniejącą infrastrukturę, w odniesieniu do której owo uznanie wiąże się z zastosowaniem szczególnego administracyjnego reżimu ochronnego i zarazem kontrolnego.

W świetle BHK nieruchomość, na której umiejscowione jest złoże oraz urządzenia niezbędne do eksploatacji złóż istotnych dla uzdrowiska muszą być objęte prawem własności wnioskodawcy lub innym prawem dającym uprawnienie prawa cywilnego ich użytkowania tym podmiotom, które korzystanie z owych złóż oferują w ramach prowadzonej działalności uzdrowiskowej ( $\$ 2$ ust. 1 BHK).

Zgodnie z przepisami tyrolskiej THK eksploatacja złoża wymaga odrębnej decyzji administracji okręgowej, która także wydawana jest na wniosek jego posiadacza ${ }^{3}$ (\$6 ust. 1-2 THK). W decyzji tej implikuje się istnienie konkretnej infrastruktury eksploatacyjnej. Dodatkowo $\$ 13$ THK dotyczący występowania miejscowości uzdrowiskowej jako podmiotu obrotu gospodarczego implikuje, że w tym zakresie musi być jasne, w oparciu o jakie złoże lub walory, i jak eksploatowane, taka miejscowość działa. Ponadto, przepis $\$ 16$ THK wymaga uzyskania koncesji na podjęcie działalności w zakresie świadczenia usług uzdrowiskowych przez każde przedsiębiorstwo (niem. Betrieb) uzdrowiskowe - we wniosku składanym administracji okręgowej takie przedsiębiorstwo musi przedstawić konkretne plany dotyczące istniejącej i planowanej infrastruktury temu służącej, a także sposobu działania przedsiębiorstwa $\mathrm{w}$ tym kontekście. Wydana koncesja uwzględnia treść decyzji organów landowych dotyczących uzdrowiska i jest tym uwarunkowana. Siłą rzeczy, ta decyzja koncesyjna obejmuje wspomnianą we wniosku infrastrukturę. Zgodnie z przepisem $\$ 16$ ust. 5 lit. b THK, warunkiem udzielenia wspomnianej koncesji jest - oprócz innych wymienionych w tym ustępie wymagan - to, by podmiot wnioskujący dysponował własnością lub innym prawem rzeczowym uprawniającym do użytkowania opisanego we wniosku przedsiębiorstwa - to zaś obejmuje wspomnianą infrastrukturę; warunkiem jest również zapewnienie odpowiedniego personelu do jej obsługi. Nowej koncesji wymagają poważniejsze zmiany we wspomnianym zakresie. Zgodnie z $\$ 18$ ust. 1-2 THK) przedsiębiorstwo, którego dotyczy koncesja, może być oddane w najem pod warunkiem zgłoszenia tego faktu administracji okręgowej, która może się temu sprzeciwić (w ciągu 2 miesięcy od otrzymania powiadomienia o tej okoliczności).

\footnotetext{
3 Niem. Inhaber. Zob. także poprzedni przypis.
} 


\section{Regulacja czeska}

W Czechach status miejscowości uzdrowiskowej nadaje Rada Ministrów (czes. Vláda) na mocy swojego rozporządzenia (czes. nař́zeni); w taki sam sposób nadawany jest takiej miejscowości status uzdrowiskowy ( $\$ 28$ ust. $1 \mathrm{LZ}$ ). Zgodnie z $\$ 25$ ust. $3 \mathrm{LZ}$ status uzdrowiska naturalnego nadaje natomiast ministerstwo poprzez obwieszczenie (czes. vyhláška). Spełnianie warunków miejscowości uzdrowiskowej należy do obowiązków gminy, na terenie której taka miejscowość się znajduje (\$28 ust. 4 LZ). Warunki, które musi spełniać uzdrowisko, są dokładniej określone w drugiej części obwieszczenia Ministerstwa Zdrowia z 20 listopada 2001 r., dotyczącego m.in. tej kwestii (tj. tzw. obwieszczenia o złożach i uzdrowiskach - czes. vyhláška o zdrojích a lázních, dalej VZL). (Vyhláška..., 2001).

Status miejscowości uzdrowiskowej jest nadawany na wniosek gminy, zaś uzdrowiska naturalnego na wniosek gminy, ewentualnie również osób fizycznych lub prawnych, które mają zamiar eksploatować złoża bądź korzystać z warunków klimatycznych w danym miejscu występujących; uzdrowisko może także ustanowić ministerstwo z własnej inicjatywy ( $\$ 25$ ust. 3 LZ). Ponieważ do wniosku o ustanowienie uzdrowiska załącza się operat dotyczący m.in. urządzeń niezbędnych do eksploatacji złóż i wykonywania działalności leczniczej, decyzja ministerstwa dotyczy także tej wspomnianej infrastruktury ( $\$ 26$ ust. 1 lit. d).

Zgodnie z $\$ 8$ ust. 1 VZL uzdrowisko spełnia zasadnicze wymogi LZ, jeżeli zapewnione jest również prawidłowe gospodarowanie gruntami uwzględniające ich klasę bonitacyjną, wielkość koniecznej infrastruktury eksploatacyjnej złóż jest dostosowana do charakteru terenu oraz wydajności tych złóż, zwiększona jest ilość zieleni w otoczeniu, jak również osiągnięto „harmonijne powiązanie rozwiązań architektonicznych i urbanistycznych z otaczającym terenem” (czes. "harmonický sepětí architektonických a urbanistických řešení s okolní krajinou”). Ustęp 2 tego przepisu wymaga odpowiedniego wydzielenia uzdrowiska od pozostałych części gminy, w której ono funkcjonuje, a także wyeliminowania źródeł hałasu i zanieczyszczeń powietrza, mogących na uzdrowisko negatywnie oddziaływać. W szczególności wymagania te muszą być spełnione w przestrzeni w promieniu $4-8 \mathrm{~km}$ od uzdrowiska, co do której VZL określa wymagania bardzo szczegółowo (np. formułując wymagania dotyczące krzyżowania ciągów powietrznych z drogami, lokalizacji autostrad, a nawet cmentarzy i zakładów karnych - z uwagi na ich możliwy negatywny wpływ na psychikę kuracjuszy, zob. $\$ 8$ ust. 7 VZL).

Wspomniany standard zwiększonej ilości zieleni w otoczeniu jest dla miejscowości uzdrowiskowej określony. Jest on spełniony wtedy, gdy na jej terytorium 4 ha terenów zielonych przypada na każde 100 lóżek przeznaczonych dla osób odwiedzających taką 
miejscowość. Zieleń taka musi być urozmaicona gatunkowo; nie powinno się tam sadzić gatunków, których pyłki są najczęściej występującymi alergenami. Regulacja VZL określa również konkretne wymagania jakości powietrza ( $\$ 9$ w związku z $\$ 13$ VZL, a w odniesieniu do uzdrowisk klimatycznych - w związku z $\$ 10$ VZL).

Jak wspomniano, zgodnie z wyraźnym zapisem $\$ 4$ ust. 1-2 LZ, złoża, w oparciu o które prowadzi się uzdrowisko, nie są uważane za części składowe ani za przynależności działek; owe złoża nie mogą być przedmiotem odrębnej własności prywatnej czy gminnej (pozostają one bowiem zawsze własnością państwa). Podmiot mający zgodę (koncesję) na eksploatację złoża nabywa jednak własność pożytków z chwilą ich pozyskania ze złoża. Warunkiem otrzymania koncesji eksploatacyjnej (która jest przypisana konkretnemu wnioskodawcy, działającemu w konkretnej formie, a nawet postaci $\left.{ }^{4}\right)$ jest to, by złoże było wpierw uznane za uzdrowiskowe. O uznaniu złoża za źródło substancji leczniczych decyduje, w oparciu o przedstawione przez wnioskodawcę (którym może być każda osoba fizyczna bądź prawna, w tym sama gmina) dowody z przeprowadzonych jego nakładem badań, właściwe ministerstwo (tj. Ministerstwo Zdrowia). Dodatkowym warunkiem uzyskania takiej decyzji są m.in. celowość i możność eksploatacji złoża oraz możliwość jego ochrony ( $\$ 5$, ust. 1 LZ). Sama koncesja jest udzielana (na podstawie $\$ 10$ w związku z $\$ 12 \mathrm{LZ}$ ) wnioskodawcom, którzy będą eksploatowali złoże na podstawie tytułu prawnego do gruntu, na którym złoże jest położone, dającego im możliwość pobierania pożytków. W takiej koncesji określone są ogólne warunki techniczne eksploatacji. Dokładne warunki eksploatacji są zaś uzgadniane pomiędzy podmiotem eksploatującym a właściwym organem na podstawie operatu przedstawionego przez eksploatującego w ciągu roku od uprawomocnienia się decyzji o udzieleniu koncesji, ocenianego w terminie $60 \mathrm{dni}$ od jego otrzymania.

Zgodnie z wyraźnym zapisem $\$ 4$ ust. 1-2 LZ, złoża, w oparciu o które prowadzi się uzdrowisko, nie są uważane za części składowe ani za przynależności działek uznanych za teren uzdrowisk; jak już wspomniano, owe złoża nie mogą być przedmiotem odrębnej własności osób fizycznych bądź prawnych - pozostają one bowiem własnością państwa. Podmiot mający zgodę (koncesję) na eksploatację złoża nabywa jednak własność pożytków z chwilą ich pozyskania ze złoża. Eksploatujący ma obowiązek posiadać jednak właściwe urządzenia do eksploatacji i je prawidłowo utrzymywać (wynika to z $\$ 16 \mathrm{LZ}$ ). Implikuje to, że w praktyce regułą jest udzielanie koncesji eksploatacyjnej złoża jedynie wtedy, kiedy podmiot wnioskujący o nią przedstawi dokumentację istniejącej infrastruktury. Także logika uznania uzdrowisk

4 Stąd np. podział spółki, której udzielono koncesji skutkuje wygaśnięciem koncesji (zob. $\$ 15$ ust. 1 pkt b LZ). 
i miejscowości uzdrowiskowych w Czechach, jak również ustanawiany reżim ochronny źródeł implikuje to, że akt ten dotyczy szeroko pojętej infrastruktury, która nie może być po uzyskaniu uznania dowolnie zmieniana.

\section{Regulacja niemiecka}

W RFN regulacja zagadnienia nadania statusu miejscowościom uzdrowiskowym jest domeną prawa landowego. Jedynym istotniejszym postanowieniem prawa federalnego (konkretnie SGB V) dotyczącym zagadnień mających znaczenie dla statusu uzdrowiska jest to, które wymaga, by właściwości środków, jakie mają być stosowane w ochronie zdrowia (w leczeniu) były zweryfikowane naukowo (\$124). Odnosi się to również do złóż, uzdrowisk oraz miejscowości uzdrowiskowych.

Przykładem regulacji landowej dotyczącej funkcjonowania uzdrowisk i miejscowości uzdrowiskowych w RFN jest krajowa Ustawa o miejscowościach uzdrowiskowych w Nadrenii-Północnej Westfalii (tzw. Kurortgesetz - dalej KOG) (Gesetz..., 2008: 8). Zgodnie z jej regulacją ( $\$ 1$ ust. 1 ), miejscowościami uzdrowiskowymi mogą być gminy albo części gmin, w których występują „naturalne środki zdrowotne” ziemi (niem. Heilmittel des Bodens) lub klimatu albo też uznanych naukowo źródeł wodnych o właściwościach terapeutycznych (niem. hydrotherapeutische Heilverfahren). Wspomnianymi „naturalnymi środkami zdrowotnymi” są w szczególności źródła wody, borowin, gazów oraz sam klimat.

Wszystkie wspomniane walory, na których opiera się działalność uzdrowiska bądź miejscowości uzdrowiskowej, muszą być naukowo zweryfikowane i okresowo badane. Źródła wody uważa się za uzdrowiskowe wtedy, kiedy zostaną za takie uznane przez właściwe organy landu Nadrenii-Północnej Westfalii. Zgodnie z przepisem $\$ 17$ ust. $1 \mathrm{w}$ związku z $\$ 2$ ust. 1 KOG status uzdrowiska jest nadawany przez organy landowe na wniosek gmin (y), które powołują się na istnienie na ich terenie „naturalnych środków zdrowotnych” (niem. natürlische Heilmittel). Zgodnie z postanowieniem $\$ 17$ ust. 2 to gminy ponoszą koszty wniosku oraz przygotowania załączonej do niego dokumentacji. Decyzja o uznaniu uzdrowiska lub miejscowości uzdrowiskowej jest promulgowana w landowym dzienniku urzędowym. Może ona zawierać postanowienia dodatkowe, określające warunki ich funkcjonowania oraz, tym samym, przesłanki przyszłej kontroli ( $\$ 18$ ust. $1 \mathrm{KOG}$ ).

Ze względu na rodzaj wspomnianych „naturalnych środków zdrowotnych” mogą one uzyskać uznanie w jednej lub wielu następujących kategorii: jako uzdrowisko (ogólne) lub uzdrowisko mineralne, termalne, solankowe, borowinowe, błotne, specjalizujące się w stosowaniu hydroterapii metodą Kneippa (niem. Kneipp-Heibad), jako klimatyczna miejscowość uzdrowiskowa (niem. Heilklimatischer Kurort), 
miejscowość uzdrowiskowa specjalizująca się w hydroterapii metodą Kneippa (niem. Kneipp-Kurort), miejscowość uzdrowiskowa ze szczególnie wartościowym powietrzem (niem. Luftkurort), a także jako miejscowość z zakładem eksploatacji źródeł (niem. Ort mit Heilquellen-Kurbertrieb), miejscowość z uzdrowiskiem korzystającym ze sztolni kopalnianych (niem. Ort mit Heilstollen-Kurbetrieb), a także jako miejscowość z zakładem eksploatacji borowin lub torfu (niem. Ort mit Peloid- oder Moor-Kurbetrieb). Przepis $\$ 2$ ust. 4 KOG wymaga, by w decyzji o nadaniu statusu uzdrowiskowego miejscowości określone były podstawowe zasady jej funkcjonowania, w tym zwłaszcza cele i wymagania dotyczące planowania przestrzennego, oraz ochrony środowiska naturalnego. Bardziej szczegółowe wymagania dotyczące działalności miejscowości określone są w $\$ 2$ ust. 5 KOG. Te dodatkowo odwołują się do jeszcze bardziej szczegółowych wymagań w zakresie funkcjonowania takich miejscowości określonych w zasadach przyjętych przez DHV oraz Niemieckie Stowarzyszenie Turystyczne (niem. Deutscher Turistmusverband e. V., DTV), a także w $\$ 3$ KOG.

Jak wspomniano, SGB V jest jedynie ramową regulacją, której postanowienia są uzupełnione zasadami przyjętymi przez DHV oraz DTV, jak również dookreślone w innych szczegółowych regulacjach prawnych. Zasady przyjęte wspólnie przez DHV i DTV (Deutscher Tourismusverband e. V. i Deutscher Heilbäderverband e. V., 2005) są sformułowane zawsze w odniesieniu do sytuacji, w których podmiot je stosujący ma jakiś tytuł prawny do złoża, pozwalający mu na jego eksploatację i bycie z tego tytułu ich adresatem. Zasady te nie zawierają jednak wyraźnych reguł dotyczących kwestii statusu prawnego złóż.

Wspomniany już przepis $\$ 3$ KOG wymaga spełnienia przez miejscowość uzdrowiskową 18 kryteriów, stanowiących razem uprawdopodobniony opis jego funkcjonowania. Regulacja ta, wraz z wymaganiami $\$ 2$ ust. 4 i 5 KOG, implikuje konieczność istnienia w danej miejscowości odpowiedniej infrastruktury służącej zarówno eksploatacji istniejących na jej terenie złóż o naukowo udowodnionych właściwościach leczniczych, jak i wykorzystania innych walorów (np. klimatycznych); owe wymagania są wyraźnie określone w innych częściach regulacji KOG, dotyczących już konkretnych typów uzdrowisk i miejscowości uzdrowiskowych (tj. w \$4-12 KOG). Wymagania określone w $\$ 3$ KOG obejmują także podjęcie odpowiednich środków (również w zakresie planowania przestrzennego) w celu zapewnienia ochrony środowiska naturalnego, w tym odpowiedniej jakości powietrza i ochrony przed hałasem.

Istnienia infrastruktury eksploatacyjnej zakładają bądź wymagają także przepisy KOG dotyczące konkretnych typów uzdrowisk. Do tego typu przepisów należą te, które określają wymagania zapewnienia dostępności źródła substancji zdrowotnych ( $\$ 8$ ust. $4 \mathrm{KOG)}$ ) albo warunkują uznanie danego uzdrowiska wtedy, gdy zbadane zostaną warunki higieniczne instalacji doprowadzających wodę leczniczą do punktu 
jej poboru przez użytkowników uzdrowiska ( $\$ 16$ ust. 2 KOG). Na to, że uznanie uzdrowiska lub miejscowości uzdrowiskowej obejmuje także infrastrukturę, wskazuje nota wyjaśniająca do BB/QS (Deutscher Heilbäderveband e. V., 2005: 35).

\section{Regulacja słowacka}

Zgodnie z $\$ 2$ ust. 9 słowackiej KZ, miejscowością uzdrowiskową jest obszar gminy lub jej część, w której znajdują się - uznane w świetle tej regulacji - naturalne złoża lecznicze, termy lecznicze lub inne urządzenia determinujące istnienie uzdrowiskowych właściwości tego terenu. Właścicielami konkretnych urządzeń infrastrukturalnych eksploatujących zasoby mogą być zarówno podmioty publiczne, jak i prywatne.

Ustanowienia miejscowości uzdrowiskowych dotyczy $\$ 35 \mathrm{KZ}$. Przewiduje on taką możliwość w procedurze, w której stosowny wniosek składa gmina lub gminy, na których terytorium spełnione są warunki ustanowienia uzdrowiska ( $\mathrm{tj}$. istnienie złóż uzdrowiskowych) - z tym zastrzeżeniem, że w wypadku wniosku wielu gmin jest on składany przez tę, na terytorium której znajduje się większość urządzeń uzdrowiskowych (ust. 1). Za uzdrowiskowe może być uznane tylko terytorium spełniające wymagania - a więc także część gminy (ust. 2). Spełnienie wymagań musi być m.in. udowodnione przez stosowny operat, na którym uwidocznione są istotniejsze dla eksploatacji zasobów uzdrowiskowych urządzenia, a także który wskazuje na brak takich okoliczności, które nie mogą istnieć na terenach uzdrowiskowych (np. intensywnej gospodarki rolnej, intensywnej hodowli zwierząt, budowli, których przeznaczenie jest sprzeczne z funkcjami uzdrowiska, składowisk odpadów itp.). Granice uznanego terenu uzdrowiskowego powinny być oznaczone nie tylko w stosownej ewidencji gruntów (prowadzonej przez urzędy katastralne, słow. katastralný úrady), lecz również w przestrzeni - w postaci tablic. W ramach tak wyznaczonego terenu obowiązuje szczególny system ochrony zasobów uzdrowiskowych oraz szczególny system monitorowania środowiska - także w sposób, który wymaga ograniczenia ogólnych uprawnień właścicielskich (\$39 KZ).

Ważnym aspektem słowackiej regulacji dotyczącej uzdrowisk jest to, że odrębnie od uznania miejscowości za uzdrowiskową, a także odrębnie od posiadania złóż uzdrowiskowych, osoba (fizyczna lub prawna) mająca zamiar wykorzystywać szczególne cechy klimatu danej miejscowości może złożyć wniosek o uznanie owych cech za właściwych do leczenia określonych schorzeń. Czyni to wtedy na podstawie $\$ 30 \mathrm{KZ}$. Stosowną decyzję ustalającą istnienie wskazanych przez wnioskodawcę i udokumentowanych przez niego właściwości podejmuje Państwowa Komisja Uzdrowiskowa (słow. Štátna kúpel’ná komisja, ŠKK). Do oceny wymogów ma zastosowanie odpowiednie obwieszczenie Ministerstwa Zdrowia wydane na podstawie delegacji 
zawartej w $\$ 30$ ust. 5 KZ. Decyzja ŠKK uznaje wskazane właściwości za lecznicze (uzdrowiskowe) w odniesieniu do określonego obszaru, charakteryzującego się tymi samymi cechami bioklimatycznymi, w tym tą samą jakością powietrza; ową tożsamość i niezmienność weryfikuje najbliższa wskazanemu przez wnioskodawcę terytorium państwowa stacja meteorologiczna - czyni to poprzez obserwację, która nie może trwać krócej niż 3 lata ( $\$ 30$ ust. 4 oraz $6 \mathrm{KZ}$ ).

Decyzje dotyczące eksploatacji złóż obejmują także ich infrastrukturę. Wynika to przede wszystkim z logiki przepisu $\$ 11$ ust. 3 lit. f KZ, który m.in. wymaga technicznego opisu sposobu tej eksploatacji. W myśl przepisu $\$ 12$ ust. $4 \mathrm{KZ}$ reżim użytkowania gruntu nad złożem może być określony także zgodnie z innymi, niedotyczącymi uzdrowisk, właściwymi regulacjami. Wyjątkowo, można otrzymać koncesję na eksploatację złoża bez posiadania odpowiedniej infrastruktury. W takim jednak przypadku przepis $\$ 15$ ust. $1 \mathrm{KZ}$ wymaga, by taki podmiot przedłożył w ciągu roku od uprawomocnienia się decyzji koncesyjnej dokumentację projektową takiej infrastruktury. Dokumentacja taka podlega ocenie ŠKK, która może żądać jej modyfikacji i może ustalić dodatkowe warunki eksploatacji złoża. W wypadku niezbudowania w ciągu 3 lat od uprawomocnienia się decyzji koncesyjnej infrastruktury uzgodnionej w ostatecznie przyjętej przez ŠKK dokumentacji koncesja automatycznie wygasa ( $\$ 15$ ust. $3 \mathrm{KZ}$ ). W przypadku uzgodnienia dokumentacji, zbudowania infrastruktury oraz ustalenia dodatkowych warunków eksploatacji przez ŠKK, ma ona obowiązek dokonać kontroli eksploatacji złoża w ciągu 15 lat od daty udzielenia koncesji i ustalić wtedy ostateczne warunki eksploatacji.

Centralnym organem władzy państwowej właściwym do spraw ustanawiania i sprawowania nadzoru nad uzdrowiskami jest słowackie Ministerstwo Zdrowia; jego organem doradczym jest wspomniana już Państwowa Komisja Uzdrowiskowa (ŠKK), której 7-osobowy skład powołuje minister zdrowia z grona ekspertów specjalizujących się w dziedzinach dotyczących uzdrowisk (na 5-letnią odnawialną kadencję). ŠKK ma również uprawnienia organu administracyjnego - zgodnie $\mathrm{z} \$ 42 \mathrm{KZ}$ ma ona samodzielne kompetencje do wydawania decyzji $\mathrm{m}$. in. w sprawie podjęcia eksploatacji złóż leczniczych; w odniesieniu do uznawania uzdrowisk ma ona jednak funkcje doradcze - zgodnie z przepisem $\$ 42$ lit. e przedkłada wnioski dotyczące uznania miejscowości za uzdrowiskową, zmiany wydanej w tym zakresie decyzji, jak również jej uchylenia.

Szczególny reżim ochronny uzdrowisk nakłada się na ogólny reżim ochrony środowiska wynikający z Ustawy z 25 czerwca 2002 r. o ochronie przyrody i krajobrazu (Zákon..., 2002). Zastosowanie przepisów tej ustawy jest tu tym bardziej prawdopodobne, że znaczna liczba uzdrowisk i miejscowości uzdrowiskowych znajduje się jednocześnie na obszarach lub blisko obszarów uznanych za szczególnie 
wartościowe w świetle $\$ 50$ tej właśnie regulacji, a przez to podlega szczególnemu reżimowi ochronnemu.

W obowiązującym na Słowacji prawie istnieje wymóg, by na terenach wskazanych we wniosku o ustanowienie miejscowości uzdrowiskowej znajdowały się złoża, które mogą być eksploatowane na cele uzdrowiskowe. Obowiązujące przepisy implikują jednak możliwość uznania miejscowości za uzdrowiskową ze względu na szczególnie wartościowy klimat i powietrze.

Nie ma w powszechnie obowiązującym prawie słowackim wyraźnie określonego i zarazem dotyczącego wszystkich typów złóż wymogu eksploatowania złóż. Na taki wymóg wskazują jednak:

a) przepis $\$ 10$ ust. $2 \mathrm{KZ}$ wymagający, by - jeżeli już złoże jest eksploatowane - jego eksploatacja odbywała się wyłącznie na cele uzdrowiskowe,

b) przepis $\$ 11$ ust. 3 lit. $f \mathrm{KZ}$ wymagający, by we wniosku o wydanie pozwolenia (koncesji) na eksploatację złoża podmiot wnioskujący zadeklarował zamiar jego wykorzystywania,

c) przepis $\$ 14$ ust. $1 \mathrm{KZ}$, wymagający utrzymania urządzeń balneotechnicznych, balneoterapeutycznych, a także gazowych w stanie technicznym określonym w innych niż KZ przepisach (Zákon..., 1999) ${ }^{5}$,

d) omówiony już przepis $\$ 15$ ust. $1 \mathrm{KZ}$, dotyczący wyjątkowej sytuacji, w której koncesja wydobywcza jest przyznana bez posiadania przez uprawnionego odpowiedniej infrastruktury eksploatacyjnej, który wyklucza możliwość utrzymania owego braku przez okres dłuższy niż 3 lata, pod rygorem automatycznego wygaśnięcia tej koncesji.

Przepisem przymuszającym do eksploatacji złoża wód mineralnych jest $\$ 11$ ust. $6 \mathrm{KZ}$. Wymaga on ponowienia badań złoża w przypadku niepodjęcia jego użytkowania w ciągu 3 lat od daty uznania pochodzącej z niego wody za naturalną wodę mineralną. Jest nim także $\$ 14$ ust. $1 \mathrm{KZ}$, który z kolei zobowiązuje eksploatującego złoże do dokonania wielu czynności dotyczących zabezpieczenia złoża, a także zapewnienia jego eksploatacji zgodnie z koncesją. W szczególności eksploatujący jest zobowiązany do poinformowania Państwowej Komisji Uzdrowiskowej (ŠKK) o podjęciu eksploatacji, a także umożliwić wykonywanie czynności kontrolnych.

Wymóg eksploatowania złoża może być także wyraźnie sformułowany w samych warunkach określanych w każdorazowej decyzji o uznaniu złoża. Wymóg posiadania infrastruktury i eksploatacji złoża wynika także z logiki systemu monitorowania

5 Te przepisy zostały zawarte w niektórych postanowieniach Ustawy 254/1999 o wymaganiach technicznych produktów i o ocenie zgodności oraz o uzupełnieniu niektórych ustaw w związku z wybranymi przepisami. 
wymogów jakościowych złóż oraz udzielania zgód (koncesji) wydobywczych, jak również - bezpośrednio - z przepisu $\$ 11$ ust. $5 \mathrm{KZ}$.

Na Słowacji własność złóż może być jedynie państwowa. Eksploatujący złoża (osoby fizyczne bądź prawne), posiadający koncesję, nabywają własność produktów złoża (tj. w sensie cywilnoprawnym - pożytków) z chwilą ich wydobycia (np. \$3 w związku z $\$ 2$ pkt $17 \mathrm{KZ}$ ). Koncesję eksploatacyjną wydaje się na wniosek podmiotu, który będzie eksploatował złoże: przedsiębiorcy - osoby fizycznej lub osoby prawnej ( $\$ 11$ ust. $1 \mathrm{KZ}$ ). Taki podmiot musi wykazać tytuł prawny do nieruchomości, na której znajduje się złoże, pozwalający na jej wykorzystywanie do celów uzdrowiskowych ( $\$ 11$ ust. $5 \mathrm{w}$ związku z $\$ 12$ ust. $1 \mathrm{KZ}$ ). W postępowaniu koncesyjnym biorą udział strony mające odnoszący się do niego interes prawny, a także gmina, na terytorium której znajduje się złoże oraz organ administracji właściwy dla spraw gospodarowania zasobami wody (słow. orgán vodnej správy).

\section{System finansowania miejscowości uzdrowiskowych}

Źródła prawa dotyczące finansowania uzdrowisk w Austrii są zróżnicowane i odzwierciedlają federalną strukturę tego państwa. Każdy z landów kształtuje ten system samodzielnie. Wszędzie opiera się on na ustanawianiu przez ich władze opłaty (taksy) uzdrowiskowej (niem. Kurtaxe) oraz innej opłaty turystycznej, którymi obłożeni są zasadniczo goście miejscowości uzdrowiskowych. W prawodawstwie tyrolskim np. kwestię tę reguluje Ustawa z 2 lipca 2003 r. w sprawie ściągania opłaty pobytowej (tzw. Tiroler Aufenthaltsabgabegesetz, dalej TAG) (Gesetz..., 2003) w związku z Ustawą z 15 grudnia 2005 r. w sprawie wspierania turystyki w Tyrolu (tzw. Tiroler Tourismusgesetz, dalej TTG) (Gesetz..., 2005). Zgodnie z $\$ 3$ TAG płatnikami opłaty są podmioty zajmujące się zarobkową działalnością noclegową ( $\mathrm{z}$ wyjątkiem osób, które użyczają do tego celu części własnych mieszkań). Opłata obciąża zaś korzystających z noclegów gości miejscowości uzdrowiskowych i uzdrowisk. Wysokość opłaty wynosi co najmniej 0,55 EUR za noc od osoby, ale organy landowe mogą zadecydować o jej podwyższeniu dla poszczególnych miejscowości do maksimum 3 EUR. Zgodnie $\mathrm{z} \$ 1$ TAG dochody z opłaty muszą być przeznaczone na rozwój turystyki. Nieco inny system finansowania działalności turystycznej w miejscowościach uzdrowiskowych, oparty na bezpośrednim, a nie pośrednim dysponowaniu środkami funduszu turystycznego, istnieje w dwóch innych zbadanych landach Austrii, tj. w Górnej Austrii oraz w Burgenlandzie. Zgodnie z ustawodawstwem Górnej Austrii, tj. z obowiązująca w nim Ustawą z 30 czerwca 1961 r. o naturalnych uzdrowiskach i miejscowościach uzdrowiskowych (tzw. Oberösterreichische Heilkommen- und Kurortegesetz, dalej OHK) 
(Gesetz..., 1961: 24) ${ }^{6}$, jak również z ustawodawstwem Burgenlandu, opłaty pobytowe (oraz inne dochody, zasadniczo analogiczne do tych stosowanych w Tyrolu) są źródłem przychodów specjalnego funduszu, który mogą tworzyć te gminy, w których działa miejscowość uzdrowiskowa (zob. $\$ 20$ ust. 2 OHK). Ma on wtedy osobną osobowość prawną, ale jego zasoby muszą być przeznaczane na funkcjonowanie wspomnianej miejscowości uzdrowiskowej. Sama wielkość opłat jest ustalona w odrębnej ustawie. W Burgenlandzie wielkość opłat jest określona w Ustawie z 23 października 2014 r. o organizacji i wspieraniu turystyki (tzw. Burgenländisches Tourismusgesetz, dalej BTG) (Gesetz..., 2014: 32). Analogiczne rozwiązanie przyjęto we wspomnianym już Tyrolu oraz Górnej Austrii. W burgenlandzkim BTG odpowiednikiem taksy uzdrowiskowej jest taksa miejscowa (niem. Ortstaxe), której parametry określa \$28-29 tej regulacji. Zgodnie z tymi przepisami, podmiotami zobowiązanymi do zapłaty owej taksy są wszyscy goście nocujący w miejscowości uzdrowiskowej (z wyjątkiem pewnych kategorii osób, np. dzieci i młodzieży do lat 14); płatnikami są zaś podmioty oferujące noclegi. Zasadniczą stawką taksy jest 1,50EUR dziennie od gościa. Może być ona jednak, decyzją rządu landowego, podniesiona do maksimum 2,5 EUR. Dochodem gminy jest 5 proc. ściągniętych kwot (z tytułu wynagrodzenia za obsługę administracyjną); pozostałą kwotę dzieli się na gminę (ta otrzymuje 15 proc.), federalny Związek Turystyki (50 proc.) oraz krajową (landową) organizację turystyki (35 proc.). Rozliczenie jest miesięczne.

Zasadniczą formą finansowania uzdrowisk i miejscowości uzdrowiskowych w Czechach są dochody z usług uzdrowiskowych ustalane za zasadzie komercyjnej albo w umowach $\mathrm{z}$ organem odpowiedzialnym za organizację świadczeń zdrowotnych w ramach systemu zabezpieczenia społecznego, jak również dochody z podatku za pobyt uzdrowiskowy lub rekreacyjny (czes. poplatek za lázeňský nebo rekreačni pobyt). Parametry tego podatku, będącego jednym z podatków lokalnych, są ustalone w Ustawie z 13 grudnia 1990 r. o opłatach miejscowych (Zákon o mistních poplatcich, dalej ZMP) (Zákon..., 1990). Oba akty funkcjonują w ramach określonych obecnie przez Ustawę z 22 lipca 2009 r. ordynacja podatkowa (Zákon..., 2009). Zgodnie z $\$ 3$ ZMP podatnikami podatku za pobyt uzdrowiskowy lub rekreacyjny są osoby fizyczne, które tymczasowo i za wynagrodzeniem za nocleg przebywają w miejscowościach uzdrowiskowych albo w miejscowościach wzmożonego ruchu turystycznego w celu leczenia lub rekreacji - chyba, że wykażą inny cel swojego pobytu. Płatnikami podatku są osoby oferujące noclegi w danej miejscowości (\$3). Podatek wynosi 13 koron

6 Analogiczne rozwiązanie przyjęto w innych landach; np. w Burgenlandzie, analogiczna Ustawa z 1963 r. zawiera podobne postanowienie w $\$ 17$. 
czeskich za 1 dzień pobytu. Uzdrowiska i miejscowości uzdrowiskowe mogą uzyskiwać dotacje i subwencje - są one jednak udzielane za zasadach ogólnych.

W Niemczech władze gminne miejscowości uzdrowiskowych (niem. Hailbäder, Kurorte, Luftkurorte, Erholungsorte) są uprawnione do nakładania opłat uzdrowiskowych na osoby fizyczne, które korzystają z noclegów i innych usług uzdrowiskowych $\mathrm{w}$ takich właśnie miejscowościach. Uprawnienie takie powstaje z chwilą uznania danej miejscowości za uzdrowiskową. Ogólna podstawa prawna ustalenia opłat uzdrowiskowych jest zawarta w prawodawstwie landowym o różnym charakterze: w szczególności w regulacjach dotyczących wszystkich opłat lokalnych albo regulacjach dotyczących jedynie opłat nakładanych w miejscowościach uzdrowiskowych. W tym pierwszym przypadku opłaty uzdrowiskowe są jedną z opłat lokalnych przewidzianych dla różnego typu miejscowości - stosowaną jedynie przez te, które mają status uzdrowiskowy. To prawo landowe określa konstrukcję tych opłat, a zwłaszcza zakres terytorialny ich stosowania. Oczywistą regułą jest, że zakres ten pokrywa się z obszarem administracyjnym tej miejscowości uzdrowiskowej, na której dana opłata ma być ściągana. Zobowiązanymi do wnoszenia opłat uzdrowiskowych są osoby korzystające z bazy noclegowej miejscowości uzdrowiskowych. Płatnikami w tym zakresie są podmioty zarobkowo świadczące usługi noclegowe. Gmina musi zapewnić administrację służącą ściąganiu opłat. Zasadą prawa RFN jest to, że przychody z tego tytułu muszą być przeznaczane na utrzymanie właściwości uzdrowiskowych miejscowości i rozwijanie infrastruktury służącej korzystaniu z nich - są więc pobierane i wykorzystywane w interesie gości owych miejscowości korzystających z ich walorów uzdrowiskowych (Deutscher Heilbäderveband e. V., 2005: 43).

Na Słowacji miejscowości uzdrowiskowe i uzdrowiska mają możliwość ściągania od osób fizycznych korzystających w nich z noclegów podatku pobytowego (słow. daň $z a$ ubytovanie). Czynią to na podstawie $\$ 37-43$ (w związku z $\$ 2$ ust. 1 lit. d) Ustawy $582 / 2004$ o podatkach lokalnych i miejscowej opłacie za odpady komunalne oraz drobne odpady budowlane (dalej ZMD) (Zákon..., 2004). Podmiotami zobowiązanymi do ściągania podatku pobytowego są świadczący usługi noclegowe, a więc nie tylko prowadzący hotele, motele, oferujące noclegi prywatne itp., lecz również prowadzący domy uzdrowiskowe, domy lecznicze, infrastrukturę pobytową źródeł leczniczych ( $\$ 37$ ZMD). Podstawą podatku jest liczba noclegów przypadających na osobę (\$39 ZMD). Stawkę podatku ustala zaś gmina właściwa dla miejsca oferowania opodatkowanych świadczeń, przy czym może ona zróżnicować ją w zależności od miejsca lokalizacji infrastruktury służącej świadczeniu usług noclegowych lub jej kategorii katastralnej; może ona także ustalić zniżki i zwolnienia z podatku ( $\$ 40 \mathrm{w}$ związku z $\$ 42$, a także $\$ 43 \mathrm{ZMD})$. W pozostałym zakresie uzdrowiska i gminy uzdrowiskowe korzystaja $\mathrm{z}$ takiego samego systemu finansowania ich działalności jak wszelkie inne gminy. 
W każdym $\mathrm{z}$ analizowanych krajowych systemów prawnych istnieje szczególna regulacja dotycząca funkcjonowania miejscowości uzdrowiskowych. W państwach unitarnych (tj. w Czechach i na Słowacji) regulacja ta jest jednolita dla całego terytorium państwa, przez co należy rozumieć, że zasadnicze kwestie regulacyjne odnoszące się do tego typu miejscowości określa prawo ustanawiane na poziomie centralnym. W państwach o strukturze federacyjnej (tj. w Austrii i RFN) prawo ustanawiane na poziomie federalnym współreguluje $\mathrm{z}$ prawodawstwem landowym kwestie funkcjonowania miejscowości uzdrowiskowych; w Niemczech prawo federalne ma w odniesieniu do tej kwestii wręcz charakter szczątkowy, podczas gdy w Austrii regulacja federalna jest relatywnie rozległa.

$\mathrm{W}$ każdym $\mathrm{z}$ analizowanych systemów prawnych regulacja ta wymaga od miejscowości, które chcą uzyskać albo utrzymać status miejscowości uzdrowiskowych, spełnienia określonych warunków środowiskowych, odzwierciedlających paradygmat medyczny o pozytywnym wpływie owych warunków na stan zdrowia osób, które mogłyby czasowo przebywać w tych miejscowościach i korzystać $\mathrm{z}$ ich oferty usługowej. Część z tych warunków, np. wymagania odnoszące się do klimatu, ma charakter obiektywny - co implikuje, że miejscowości nie mają na nie w ogóle wpływu; część jednak jest uwarunkowana przez realizowaną na miejscu politykę publiczną, której skutkiem jest zaniechanie określonych inwestycji infrastrukturalnych czy gospodarczych. Stąd, aby uzyskać status uzdrowiskowy albo go utrzymać, takie miejscowości muszą rezygnować z określonych strategicznych kierunków rozwoju, co znajduje swoje odzwierciedlenie w przyjmowanych decyzjach inwestycyjnych i w zakresie planowania gospodarczego. W zamian uzyskują one korzyści wynikające z możliwości świadczenia przez zlokalizowane na ich terytorium podmioty gospodarujące usług z zakresu szeroko rozumianych świadczeń zdrowotnych (finansowanych zarówno przez sektor prywatny, jak i publiczny), a także ze szczególnych źródeł dochodów budżetu lokalnego, jakimi są specjalne podatki uzdrowiskowe. Dominującą cechą owych dochodów budżetowych jest to, że są one „znaczone” - tzn., że muszą być przeznaczone na rozwój cech i funkcji uzdrowiskowych danej miejscowości. Warto podkreślić, że w badanych systemach prawnych nie stwierdzono szczególnego, dostępnego jedynie dla miejscowości uzdrowiskowych i dla nich zaprojektowanego, systemu subwencjonowania $\mathrm{z}$ budżetów regionalnych czy centralnych.

W każdym $z$ analizowanych reżimów prawnych przyjęte regulacje pełnią funkcję gwarancyjną - mają bowiem zapewnić wiarygodność informacji o występujących w poszczególnych kurortach cennych dla dobrobytu osób, które przebywają w nich czasowo, właściwościach naturalnych. Konieczność utrzymania tych właściwości 
powoduje w tych miastach ograniczenie wyborów strategii rozwojowych do takich, które można określić jako ekstensywne gospodarczo, tzn. które są nakierowane na rozwijanie jedynie działalności niepogarszającej warunków naturalnych albo obliczonej na zgodną z zasadami zrównoważonego rozwoju eksploatowania źródeł naturalnych.

\section{Bibliografia}

Bundesgesetz vom 2. Dezember 1958 über naturliche Heilvorkommen und Kurorte, BGBl 1958, nr 272: 75; zmienione na mocy Ustawy federalnej z 3 listopada 1995 r. w sprawie uzdrowisk i miejscowości uzdrowiskowych (Bundesgesetz vom 3. November 1995, mit dem das Budesgesetz über natürliche Heilvorkommen und Kurorte geänder wird), BGBl 1995, nr 731: 243).

Deutscher Heilbäderveband e. V., Kommentierte Fassung der Befriffsbestimmungen-Qualitätstandards für die Prädikatisierung von Kurorten, Erholungsorten und Heilbrunnen, 12. Auflage, Mai 2005: 35, ostatnio zmieniony 30 października 2011.

Deutscher Tourismusverband e. V.i Deutscher Heilbäderverband e. V., Bergriffsbestimmungen/ Qualitätsstandards für Heilbäder und Kurorte, Luftkurorte, Erholungsorte - einschließlich der Prädikatisierungsvoraussetzungen - sowie für Heilbrunnen und Heilquellen, 12. Auflage, kommend aus April 2005 (wersja ostatnio zmieniona w październiku 2011 r.).

Dormandy, T. (1999). The White Death: A History of Tuberculosis. London: Hambelton Press.

Dyrektywa Komisji 2003/40/WE z 16 maja 2003 r. ustanawiająca wykaz, stężenie graniczne i wymogi w zakresie etykietowania dla składników naturalnych wód mineralnych oraz warunki zastosowania powietrza wzbogaconego w ozon do oczyszczania naturalnych wód mineralnych i wód źródlanych, Dz. U. 126: 34.

Dyrektywa Rady 80/777/EWG z 15 listopada 1980 r. w sprawie zbliżenia ustawodawstw Państw Członkowskich w zakresie wydobywania i wprowadzania do obrotu naturalnych wód mineralnych, Dz. U. 1980, L 229: 1 (ze zmianami).

Gesetz über Kurorte im Land Nordrhein-Westfalen (Kurortgesetz) vom 11. Dezember 2007, GV. NRW. 2008: 8.

Gesetz vom 23. Oktober 2014 über die Organisation und Förderung des Tourismus im Burgenland, LGBl. für das Burgenland, 2014, nr 63: 32.

Gesetz vom 30. Juni 1961 über natürliche Heilvorkommen und Kurorte, LGBl. für Oberösterreich, 1961, nr 47: 24.

Gesetz vom 4. Februar 2004 über natürliche Heilvorkommen und Kurorte (Tiroler Heilvorkommen - und Kurortegesetz), LGBl für Tirol, nr 24: 9.

Gesetz von 15. Dezember 2005 zur Förderung des Tourismus in Tirol, LGBl 2006, nr 19 (ze zmianami).

Gesetz von 2. Juli 2003 über die Erhebung einer Aufenhaltsabgabe, LGBl 2003, nr 85 (ze zmianami). Gesetz von 20. Dezember 1988 Sozialgesetzbuch, Fünftes Buch V-Gesetzliche Krankenversicherung, BGBl I: 2477. 
Nowak-Far, A. (2017). Specjalne podatkowe źródła finansowania miejscowości uzdrowiskowych w Austrii, Czechach, Niemczech i na Słowacji. Finanse Komunalne, nr 3(218): 13-22.

Vyhláška Ministerstva zdravotnictví zed ne 20. listopadu 2001, kterou se stanowi způsob a rozsah hodnocení prirodních léčivých zdrojů, přirodních minerálních vod a dalši podrobnosti jejich využívání, požadavky na životni prostředí a vybavení přirodních léčebných lázní a náležitosti odborného posudku o využitelnosti přirodních léčivých zdrojů a klimatických podmínek k léčebným účelưm, přirodní minerálbný vody $k$ výrobě přirodních minerálních vod a ostavu životního prostředí prírodních léčebných lázni, č. 423/2001 Sb.

Zákon z 13. prosince 1990 r. o místních poplatcich č. 565/1990 ze zmianami.

Zákon z 23. septembra 2004 o miestnych daniach a miestnom poplatku za komunalne odpady a drobne stavebné odpady, č. 582/2004 Z. z.

Zákon z 25. júna 2002 o ochrane prirody a krajiny, č. 543/2002 Z. z.

Zákon z 27. októbra 2005 o prírodných liečivých vodách prírodných liečebných kúpel'och, kúpel'ných miestach a prírodných minerálnych vodách a o zmene a doplnení niektorých zákonov, č. 538/2005 Z. z.

Zákon z 7 septembra 1999 o technických požiadavkách na výrobky a o posudzovani zgody a o zmene a doplnení niektorých zákonov v zneni neskoríśích przedpisov, č. 264/1999.

Zákon ze dne 13. dubna 2001 o prírodních léčivých zdrojích, zdrojích přirodních minerálních vod, prírodních léčebných lázních a lázeňských mistech a o změně některých souvisejících zákonů (lázeňský zákon), č. 164/2001 Sb.

Zákon ze dne 22. července 2009 daňovy řad, č. 280/2009 Sb. 